\author{
Dr. sc. Maša Marochini, viša asistentica \\ Pravnog fakulteta Sveučilišta u Rijeci
}

\title{
THE INTERPRETATION OF THE EUROPEAN CONVENTION ON HUMAN RIGHTS
}

\author{
UDK: 342.7 (4) 341 \\ Pregledni znanstveni rad \\ Primljeno: 27. 10. 2013.
}

The European Convention Human Rights system, despite being the most effective system in providing individual protection of civil and political rights, is currently facing numerous problems. One of the biggest problems is the European Court of Human Rights overload. The expansion of the Court's caseload can be attributed to a combination of several factors one of which is the extensive judicial interpretation of Convention rights to a variety of claims, which at the inception of the system states were not initially intent upon addressing. As a human rights treaty where numerous provisions have been drafted with a lack of precision the Convention is subject to interpretation that is done by the Court since the judges have to interpret and define law in concrete situations, and not just apply it. For that reason the Court has developed numerous principles of interpretation of the Convention and this paper looks at the most important ones. The interpretative principles of the Court can be divided in two groups, related to the direction in which the judicial creativity led. The first group represents judicial self-restraint principles of interpretation where the judges used one of the four following principles: intentionalism, textualism, margin of appreciation or the doctrine of fourth instance. On the other side, the judicial activist methods of interpretation, as used by the judges' of the Court are the living instrument doctrine or evolutive interpretation, the doctrine of effectiveness or innovative interpretation, and the doctrine of an autonomous concept. This paper will look at all those principles as well as at the negative consequences of the inconsistency of their use.

Key words: ECHR, ECtHR, Law of the Convention, Strasbourg

\section{INTRODUCTION}

The European Convention on Human Rights (the Convention, ECHR) ${ }^{1}$ is an international treaty drafted within the Council of Europe $(\mathrm{CoE})$ in 1949 , opened for signature in 1950, and entered into force in 1953. It provided a basic catalogue of human rights with three institutions responsible for its enforcement, the European Commission of Human Rights (the Commission), the Committee of Ministers (CoM) and the European Court of Human Rights (the Court). Over the years, the Convention was amended several times through the addition of Protocols. ${ }^{2} \mathrm{New}$

${ }^{1}$ The European Convention on Human Rights 1950, 87 UNTS 103; ETS 5.

${ }^{2}$ Protocol No.1 213 UNTS 262, ETS 9, adopted in 1952 and in force since 1954; Protocol No. 41469 UNTS 263, ETS 46, adopted in 1963 and in force since 1968; Protocol No. 41469 UNTS 263, ETS 46, adopted in 1963 and in force since 1968; Protocol No. 6 ETS 114, adopted in 1983 and in force since 1985; Protocol No. 7 ETS 117, adopted in 1984 and in force since 1988; Protocol No. 12 ETS 177, 8 IHRR 884 (2002); and Protocol No. 13 ETS 187, 9 IHRR 884 (2002). 
human rights were added to the original list. In 1998, the previous Commission and the old Court, which both had set on a part-time basis, were replaced by the single permanent Court. The right of individuals to petition the new Court became compulsory for Contracting States. ${ }^{3}$ In order to enable the new Court to better fulfil its mission further procedural changes were made in 2010. ${ }^{4}$ Following the accession to the Council of Europe of new states from Central-East and South-East Europe and the former Soviet Union, the Convention system now encompasses almost the entire European continent, with its 47 Contracting States (only Belarus, the Holy See and Kazakhstan are exceptions), and covers 822 million people. ${ }^{5}$ It is the oldest and the most effective system for the protection of human rights in the world.

The Convention system, despite being the most effective system in providing individual protection of civil and political rights, is currently facing numerous problems. One of the biggest problems is the Court's overload. In 201265,150 applications were allocated to a judicial formation, an overall increase of $1 \%$ compared with $2011 .^{6}$ Therefore, the caseload continues to grow constantly. One way of dealing with the large number of applications was the introduction of the Protocol 14 that made important changes to the Convention system. The first important change brought by Protocol 14 was the introduction of a single judge. ${ }^{7}$ The second major change introduced was the expansion of the powers of threejudge Committees. ${ }^{8}$ These changes represent an attempt to increase the efficiency of the Court at a time when it is facing a case overload. The third major change was the most controversial one since it introduces a new admissibility criterion for individual applications. ${ }^{9}$ However, despite these changes, the caseload continues to grow constantly and it is clear now that the changes introduced by Protocol 14 will not be sufficient. At the High-level Conference held in Izmir, Turkey in 2011 which ended with the Izmir Declaration the participants concluded "Considering that the provisions introduced by Protocol No. 14, while their potential remains to be fully exploited and the results so far achieved are encouraging, will not provide a lasting and comprehensive solution to the problems facing the Convention system." 10

The expansion of the Court's caseload can be attributed to a combination of

\footnotetext{
${ }^{3}$ Protocol No. 11 ETS 155, 1-3 IHRR 206 (1994).

${ }^{4}$ Protocol No. 14 ETS 194, 9 IHRR 884 (2002).

${ }^{5}$ For thorough analysis of the history and development of the Convention system, see Ed Bates, The Evolution of the European Convention on Human Rights: From Its Inception to the Creation of a Permanent Court of Human Rights (OUP 2010).

${ }^{6}$ ECHR-Analysis of Statistics 2012, 4.

${ }^{7}$ ECHR, Article 26.

${ }^{8}$ Ibid, Article 28.

${ }^{9}$ Ibid, Article 35 (3)(b) ("The Court shall declare inadmissible any individual application submitted under Article 34 if it considers that: b) the applicant has not suffered a significant disadvantage...").

${ }^{10}$ High Level Conference on the Future of the European Court of Human Rights organised within the framework of the Turkish Chairmanship of the Committee of Ministers of the Council of Europe. Izmir, Turkey, 26 - 27 April 2011, Izmir Declaration, point 8.
} 
several factors. Some of the reasons for this situation are the greater awareness of individuals of their rights; the enlargement of the Council of Europe $(\mathrm{CoE})$ with the accession of Central and Eastern European states; and, most importantly for this paper, the Court's broad interpretation of Convention rights. ${ }^{11}$ This article discusses and analyses the interpretative principles used by the Court when interpreting the Convention since it was the use of various interpretative principles that allowed the judges of the Court to extend the scope of certain Convention rights.

\section{JUDICIAL CREATIVITY}

Despite the idea of legal positivists that lawyers' only task should consist of learning what the positive law actually is, the fact is that no law, especially not a human rights law can speak with absolute clarity in all possible situations. The indeterminacy of language itself has as a consequence that no legal text can ever have a wholly precise meaning or determinate range of application. ${ }^{12}$ This particularly goes for the Convention where numerous provisions were drafted with a lack of precision. ${ }^{13}$ But even if the Convention was drafted with more precision in its terms, the judges would still have to interpret and define law in concrete situations, and not just apply it. The fact is that at some point every judge ${ }^{14}$ will have to deal with the issue of interpreting the law and at that point the judge will approach the issue either through the ideology of judicial self-restraint or through the judicial activist ideology. ${ }^{15}$

Judicial self-restraint as an ideology takes as its premise the proposition that the judge's job is to apply the law and not to make it. However, when a new

\footnotetext{
${ }^{11}$ For example, judgments by which the Court reads into the Convention rights with significant socioeconomic elements not guaranteed under the Convention but under the European Social Charter and the European Convention for the Prevention of Torture and Inhuman or Degrading Treatment or Punishment. See: Maša Marochini, Indivisibility and Interdependence of Human Rights: Should there be limits to the European Court of Human Rights reading significant socio-economic elements into Convention Rights? Doctoral thesis (University of Dundee, 2012).

${ }^{12}$ Paul Mahoney, 'Judicial activism and judicial self-restraint in the European Court of Human Rights: two sides of the same coin' (1990) 11 Hum.Rts.L.J. 57, 60

${ }^{13}$ During the travaux preparatoires of the Convention there were numerous suggestions for more precision in provisions, however, at the end, an approach that all the experts, members of the preparatory committee agreed upon was that most of the provisions will not be drafted precisely. See, for example preparatory work on Article 3: Library of the European Court of Human Rights, "Travaux preparatoires" of the Convention, Article 3, <http://www.echr.coe.int/library/DIGDOC/Travaux/ECHRTravaux-ART3DH\%2856\%295-EN1674940.pdf>, 2.

${ }^{14}$ The fact is that judges in common law systems have more flexibility than judges in civil law systems. However, the judges in common law systems are constrained by the law of precedents, so their flexibility also has strong limits.

${ }^{15}$ Judicial activity, according to Judge Popovic should not be used as a term, because judges simply do not legislate. Dragoljub Popović, The Emergence of the European Human Rights Law, An Essay on Judicial Creativity (Eleven International Publishing 2011), 44. However, the author will use to term for the easier distinction when analysing the Court's interpretative principles, although she agrees that both principles of adjudicating represent a judicial creativity.
} 
situation arises even a judge that supports the ideology of judicial restraint will have to make a new law since he has to decide every case that comes before it. ${ }^{16}$ On the other hand, the ideology of judicial activism takes an opposite position and it encourages the judges to develop the law.

In the most general terms judges are unable to escape two fundamental constraints. First is the text itself, concerning a fair amount of possibilities, but however limiting the judges' choice, no matter how large the scope of their freedom in this respect may be. The second constraint are social problems demanding solutions, as well as ideas governing approaches to those and the way of life and usual behaviour practised in the community that puts limits to judges and their freedom of choice when deciding cases. ${ }^{17}$

\subsection{JUDICIAL CREATIVITY AND THE EUROPEAN COURT OF HUMAN RIGHTS}

The Convention itself gives no guidance on how the Court should interpret its provisions. However, from the perspective of public international law, since the Convention is a multilateral international treaty its interpretation should be governed by the Vienna Convention on the Law of Treaties 1969 (VCLT),${ }^{18}$ as it is part of the customary international law. ${ }^{19}$ The VCLT contains written rules of interpretation that, although were not in force at the time when the Convention was adopted, nowadays apply to international treaties. ${ }^{20}$ Although during the early years of its work the Court seemed willing to endorse the use of the VCLT Principles,$^{21}$ very soon it became clear that the Court will seldom invoke them. However, "though its decisions have been very much influenced by certain characteristics of the European Convention, the Court's approach to interpretation has its basis in the Vienna Convention." 22

The basic rule and the main guideline for interpretation is Article 31 of the VCLT which states that a treaty "shall be interpreted in good faith in accordance

${ }^{16}$ J.G.Merrills, The development of international law by the European Court of Human Rights (Manchester University Press 1990), 208.

${ }^{17}$ Ibid, 20.

${ }^{18}$ Done at Vienna on 23 May 1969 and entered into force on 27 January 1980. United Nations, Treaty Series, vol. 1155, 331 The VCLT is not strictly speaking applicable to the ECHR because it is not retrospective (see Article 4). So what is applied is custom, which the Court takes to be the same as the VCLT (see e.g., Golder v United Kingdom (1979-80) 1 E.H.R.R. 524, [33-34]).

${ }^{19}$ Alastair Mowbray, 'The Creativity of the European Court of Human Rights' (2005) 5 Hum. Rts. L. Rev. 57. See also Ulf Linderfalk, On the Interpretation of Treaties, The Modern International Law as Expressed in the 1969 Vienna Convention on the Law of Treaties (Springer 2010).

${ }^{20}$ Karl Zemanek on Vienna Convention on the Law of Treaties, United Nations Audiovisual Library of International Law <http://untreaty.un.org/cod/avl/pdf/ha/vclt/vclt-e.pdf> accessed 13 August 2013, (when quoting the International Court of Justice in the Arbitral Award of 31 July 1989 that stated: “...(a)rticles 31 and 32 of the Vienna Convention on the Law of Treaties... may in many respects be considered as a codification of existing customary international law..." (I.C.J. Reports 1991, 69-70 [48]).

${ }^{21}$ For example, see Golder v United Kingdom (n 18) [33]-[34].

${ }^{22}$ Merrills (n 16), 69. 
with the ordinary meaning to be given to the terms of the treaty in their context and in the light of its object and purpose" 23

An important feature of the Convention's rights is that most of them were drafted in a way as to allow a broad interpretation of the guarantees it contains. ${ }^{24}$ The indeterminacy of language itself has as a consequence lack of precise meaning or determinate range of application. ${ }^{25}$ To date, the Court has developed numerous interpretative principles of the Convention besides the use of the rules from the VCLT.

The Convention's Preamble invokes the maintenance and further realization of human rights and fundamental freedoms, which could be interpreted as revealing dynamic and evolutive character of the Convention. ${ }^{26}$ Numerous terms, like 'torture, inhuman and degrading treatment or punishment', 'criminal charge', 'private life', 'necessary in a democratic society' needed further interpretation and clarification. The interpretative principles of the Court can be divided in two groups, related to the direction in which the judicial creativity led. The first group represents judicial self-restraint principles of interpretation where the judges used one of the four following principles: intentionalism, textualism, doctrine of margin of appreciation, and the doctrine of fourth instance. ${ }^{27}$ The judicial activist principles of interpretation, as used by the judges' of the Court are the living instrument doctrine or evolutive interpretation, the doctrine of effectiveness or innovative interpretation, and the doctrine of an autonomous concept.

\section{JUDICIAL SELF-RESTRAINT PRINCIPLES OF THE INTERPRETATION OF THE CONVENTION}

In this section four self-restraint interpretative principles as used by the Court will be discussed:

- Intentionalism;

- Textualism; and

- $\quad$ The doctrine of margin of appreciation

- $\quad$ The doctrine of fourth instance

${ }^{23}$ VCLT (n 18), Article 31(1).

${ }^{24}$ For the Convention's preparatory work see:

<http://echr.coe.int/echr/en/50/50_Preparatory_Works> accessed 13 July 2013.

${ }^{25}$ Mahoney, 'Judicial activism and judicial self-restraint...' (n 12), 60.

${ }^{26}$ The Convention, Preamble.

${ }^{27}$ Regarding the right to a fair trial the Court has often invoked the doctrine of fourth instance but it is not often used regarding other Convention provisions and is usually not mentioned as a tool of interpretation by the authors that write on the Court's interpretative principles. Dragoljub Popović wrote on this doctrine, while the other authors only mentioned it in the introduction to the chapter on the right to a fair trial. See Popović, The Emergence of the European Human Rights Law... (n 12), 135-137; David Harris, Michael O'Boyle and Colin Warbrick, Law of the European Convention on Human Rights $\left(2^{\text {nd }} \mathrm{ed}\right.$,

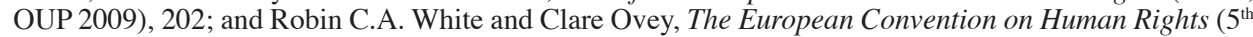
ed, OUP 2010), 140. 


\subsection{INTENTIONALISM}

Intentionalism as an interpretative principle places an emphasis on the parties' intentions at the time when the Convention was drafted. Although it is rarely used, to date, whenever the judges feel that it is necessary or appropriate, they look at the preparatory work (travaux preparatoires), but always as a supplementary principle, as Article 32 of the VCLT directs. ${ }^{28}$

In general, the Court used the preparatory work to explain its narrow interpretation of a certain provision. In its earlier judgments the Court referred to preparatory work more often while nowadays it is rarely used. However, in a rather recent case, Banković and Others $v$ Belgium and Others ${ }^{29}$ the Court invoked intentionalism. In the instant case, the Grand Chamber, when deciding whether NATO's bombing of Serbia fell within the jurisdiction of contracting states under Article 1, stated:

"However, the scope of Article 1, at issue in the present case, is determinative of the very scope of the Contracting Parties' positive obligations and, as such, of the scope and reach of the entire Convention system of human rights' protection as opposed to the question, under discussion in the Loizidou case (preliminary objections), of the competence of the Convention organs to examine a case. In any event, the extracts from the travaux préparatoires detailed above constitute a clear indication of the intended meaning of Article 1 of the Convention which cannot be ignored. The Court would emphasise that it is not interpreting Article 1 "solely" in accordance with the travaux préparatoires or finding those travaux "decisive"; rather this preparatory material constitutes clear confirmatory evidence of the ordinary meaning of Article 1 of the Convention as already identified by the Court (Article 32 of the Vienna Convention 1969)." 30

Therefore, after years of rejecting intentionalism, in Banković case the Court expressly invoked preparatory work in order to reject other interpretative tools. ${ }^{31}$

\subsection{TEXTUALISM}

The interpretation in accordance with the textualist approach is looking for a meaning of the provision as it had at the time when it was drafted or enacted, as well as the ordinary meaning of its terms. According to P. Brest "Textualism takes the language of a legal provision as the primary or exclusive source of law (a) because of some definitional or supralegal principle that only a written text can impose constitutional obligations, or (b) because the adopters intended that the

\footnotetext{
28 "Confronted with a text whose interpretation has given rise to such disagreement, the Court considers it proper to have recourse to the travaux préparatoires as a supplementary means of interpretation (see Article 32 of the Vienna Convention on the Law of Treaties)." James and Others v United Kingdom (1986) 8 E.H.R.R. 123 [64]. See also Nolan and K. v Russia (2011) 53 E.H.R.R. 29 [48].

${ }^{29}$ Bankovic and others $v$ Belgium and Others (2007) 44 E.H.R.R. SE5 (decision on admissibility).

${ }^{30}$ Ibid [65].

${ }^{31}$ Ibid, "Had the drafters wished for what is effectively a "cause-and-effect" type of responsibility, they could have adopted wording similar to that of Article 1 of the Geneva Conventions 1949.", [41].
} 
Constitution be interpreted according to a textualist canon, or (c) because the text of a provision is the surest guide to the adopters' intention." 32

When invoking ordinary meaning the Court most frequently also invokes Article 31(1) of the VCLT that requires from the judges to interpret the provisions of an international treaty in accordance with their ordinary meaning together with the interpretation in the light of its object and purpose. Furthermore, the Court has used an ordinary meaning of the Convention provisions by referring to the ordinary meaning of the rights protected under these provisions. For example, in the case Johnston and Others $v$ Ireland the Court found that no right to divorce can be derived from the right to right to marry as expressed under Article 12. ${ }^{33}$

The two interpretative principles presented, intentionalism and textualism, are not very often used nowadays, so they will not be given more attention in the paper, but it would be an understatement to say that they are completely abandoned. ${ }^{34}$

\subsection{THE DOCTRINE MARGIN OF APPRECIATION}

Today, the most commonly used self-restraint principle of interpretation is the doctrine of margin of appreciation. ${ }^{35}$ Margins of appreciation represent the "outer limits of schemes of protection, which are acceptable to the Convention." ${ }^{36}$ The legal basis of the doctrine may be found in jurisprudence of the French Conseil d'état, which has used the term "marge d'appréciation", as well as in that of the administrative law system within every civil jurisdiction. ${ }^{37}$

The doctrine of margin of appreciation has been developed in order to allow the states a space for manoeuvre that the Strasbourg organs are willing to grant

\footnotetext{
${ }^{32}$ Paul Brest, 'The Misconcieved Quest for the Original Understanding', (1980) 60 Boston University Law Review 204, 205.

${ }^{33}$ Johnston and Others $v$ Ireland (1987) 9 E.H.R.R. 203

${ }^{34}$ For more on these principles see George Letsas, A Theory of Interpretation of the European Convention on Human Rights (OUP 2009), 68-72.

${ }^{35}$ Description of a margin of appreciation as a doctrine of judicial self-restraint can be seen in judgment Cossey v United Kingdom (1991) 13 E.H.R.R. 622 where Judge Martens, in his dissenting opinion stated that "States do not enjoy a margin of appreciation as a matter of right, but as a matter of judicial selfrestraint. Saying that the Court will leave a certain margin of appreciation to the States is another way of saying that the Court - conscious that its position as an international tribunal having to develop the law in a sensitive area calls for caution - will not fully exercise its power to verify whether States have observed their engagements under the Convention, but will find a violation only if it cannot reasonably be doubted that the acts or omissions of the State in question are incompatible with those engagements." [3.6.3]. See also Paul Mahoney, 'The Doctrine of the Margin of Appreciation under the European Convention on Human Rights: Its Legitimacy in Theory and Application in Practice' (1998) 19(1) Hum.Rts.L.J. 1; Jeffrey A Brauch, 'The Margin of Appreciation and the Jurisprudence of the European Court of Human Rights: Threat to the Rule of Law' (2004-2005) 11 Colum. J. Eur. L. 113; and Ronald St.J. Macdonald, 'The Margin of Appreciation' in Ronald St.J. Macdonald, Franz Matscher and Herbert Petzold (eds), The European System for Protection of Human Rights (Martinus Nijhoff Publishers 1994).

${ }^{36}$ White and Ovey (n 27) 80.

37 Council of Europe, The Margin of Appreciation, <http://www.coe.int/t/dghl/cooperation/ lisbonnetwork/themis/ECHR/Paper2_en.asp\#P65_400> accessed on 13 August 2013.
} 
Dr. sc. Maša Marochini: The interpretation of the European Convention Human Rights Zbornik radova Pravnog fakulteta u Splitu, god. 51, 1/2014., str. 63.- 84.

national authorities, in fulfilling their obligations under the Convention ${ }^{38}$ and since some interpretation toll was necessary "to draw the line between what is properly a matter for each community to decide at local level and what is so fundamental that it entails the same requirement for all countries whatever the variations in tradition and culture." ${ }^{39}$ The margin of appreciation doctrine cannot be found in the text of the Convention ${ }^{40}$ but it was developed by the Strasbourg organs themselves in order to stress the Court's subsidiary role.

The margin of appreciation doctrine has been used by the Court regarding numerous issues. It has been used in the jurisprudence of Article $15{ }^{41}$ of Articles $8-11,{ }^{42}$ and of Article 2 of Protocol $1 .{ }^{43}$ It has also been used in the jurisprudence of Article 14, ${ }^{44}$ of Article 1 of Protocol $1,{ }^{45}$ of Article $6,{ }^{46}$ and of Article 3 of Protocol $1 .{ }^{47}$ The rights protected under Articles 2, 3 and 4 of the Convention have been considered as rights generating absolute obligations for the Member States and banning any incomplete application. ${ }^{48}$

It is commonly used by the Court as a principle of judicial self-restraint, allowing states a certain amount of discretion. However, the width of the margin of appreciation allowed to states varies in degrees of discretion, depending on the context. For that reason, the margin of appreciation can sometimes be narrow and then states will be granted little discretion. No strict conclusion can be drawn as to when the Court will use broad and when it will use a narrow approach. Even when it comes to the same case, it was sometimes decided differently by the Grand

${ }^{38}$ Steven Greer, The Margin of Appreciation: Interpretation and Discretion under the European Convention on Human Rights (CoE 2000), 5.

${ }^{39}$ Mahoney, 'The Doctrine of the Margin of Appreciation...(n 35), 1

${ }^{40}$ However, Protocol 15 to the Convention (not in force yet, but opened for signature on 24 June 2013) in its Article 1 amends the Preamble to the Convention and reads as follows: "Affirming that the High Contracting Parties, in accordance with the principle of subsidiarity, have the primary responsibility to secure the rights and freedoms defined in this Convention and the Protocols thereto, and that in doing so they enjoy a margin of appreciation, subject to the supervisory jurisdiction of the European Court of Human Rights established by this Convention."

${ }^{41}$ Lawless v Ireland (No.3) (1979-80) 1 E.H.R.R. 15; Ireland v United Kingdom (1979-80) 2 E.H.R.R. 25.

${ }^{42}$ Sahin v Turkey (2007) 44 E.H.R.R. 5; Otto-Preminger Institut v Austria (1995) 19 E.H.R.R. 34; Muller v Switzerland (1991) 13 E.H.R.R. 212; Open Door and Dublin Well Women v Ireland (1993) 15 E.H.R.R. 244; Chapman v United Kingdom (n 11); and Goodwin v United Kingdom (2002) 35 E.H.R.R. 18.

${ }^{43}$ Lautsi and Others $v$ Italy App no 30814/06 (GC judgment, 18 March 2011) and (ECtHR, 3 November 2009); Folgero and Others v Norway (2008) 46 E.H.R.R. 47; Oršuš and Others v Croatia (2011) 52 E.H.R.R. 7; D.H. and Others v Czech Republic (2008) 47 E.H.R.R. 3.

${ }^{44}$ Belgian Linguistic case (1979-80) 1 E.H.R.R. 252; Abdulazis, Cabales and Balkandali v United Kingdom (1985) 7 E.H.R.R. 471; Frette v France (2004) 38 E.H.R.R. 21. (n 18).

${ }^{45}$ Sporrong and Lonnroth $v$ Sweden (1983) 5 E.H.R.R. 35; James and Others $v$ United Kingdom

${ }^{46}$ Golder v United Kingdom (n 18); Ruiz Torija v Spain (1995) 19 E.H.R.R. 553.

${ }^{47}$ Krasnov and Skuratov v Russia (2008) 47 E.H.R.R. 46; Hirst v United Kingdom (No.2) (2006) 42

E.H.R.R. 41; Campagnano v Italy (2009) 48 E.H.R.R. 43.

${ }^{48} \mathrm{CoE}$, The Margin of Appreciation (n 37). 
Chamber then it was by the Chamber. ${ }^{49}$ Nevertheless, it can be said that more often the Court uses this doctrine to stress the Convention's subsidiary role and thereby as a self-restraint principle.

\subsubsection{The margin of appreciation doctrine in the jurisprudence of Article 15}

Article 15 of the Convention provides for the possibility of derogation "in times of war or other public emergency threatening the life of nation." Derogation may be used to the extent strictly required by the exigencies of the situation, provided that such measures are not inconsistent with the state's other obligations under international law. In the first case decided by the Court, Lawless v Ireland ${ }^{50}$ the Strasbourg institutions stated that although the decision on whether an emergency exists was primarily on the concerned government, it was not conclusive. Also, the main question was whether public authorities acted in a manner strictly required by the exigencies of the situation in accordance with Article 15(1).

Regarding possible derogations under Article 15, the Court (and the former Commission) on numerous occasions stressed that:

"By reason of their direct and continuous contact with the pressing needs of the moment, the states are in a better position than the international judge to decide both on the presence of such an emergency and on the nature and the scope of derogations necessary to avert it. In this matter Art.15 (1) leaves the authorities a wide margin of appreciation." 51

Nevertheless, Contracting Parties do not enjoy an unlimited power of appreciation. It is for the Court to determine whether the states have gone beyond the extent strictly required by the exigencies of the crisis, giving "appropriate weight to such relevant factors as the nature of the rights affected by the derogation, the circumstances leading to, and the duration of the emergency situation." 52 However, most governmental actions defended under Article 15 have been upheld.

\subsubsection{The margin of appreciation doctrine in the jurisprudence of Articles 8-11 (and of Article 2 of Protocol No. 1)}

Most of the cases concerning the use of the doctrine of margin of appreciation were regarding Articles 8-11 (and Article 2 of Protocol No. 1) since under these provisions the state can invoke a limitation of a guaranteed right by stating that those restrictions are necessary in a democratic society for legitimate aims enlisted. Within these cases the width of the margin of appreciation assigned to the states varies a great deal, since the applications themselves can involve a violation of a high spectrum of rights. The seminal case in the Court's development of the

\footnotetext{
${ }^{49}$ See Hatton and Others $v$ United Kingdom (2003) 37 E.H.R.R. 28 (GC judgment) and (2002) 34 E.H.R.R. 1; Lautsi and Others $v$ Italy (n 43).

${ }^{50}$ Lawless v Ireland ( $\left.\mathrm{n} 41\right)$.

${ }^{51}$ Brannigan and McBride v United Kingdom (1994) 17 E.H.R.R. 539, [43]; Ireland v United Kingdom (1979-80) 2 E.H.R.R. 25 [201].

${ }^{52}$ Brannigan and McBride v United Kingdom (n 51) [43].
} 
margin of appreciation doctrine was Handyside $v$ United Kingdom. ${ }^{53}$ The case involved the publication of a book called the Little Red Schoolbook which targeted young readers and mixed generally liberal social advice with controversial encouragements. After receiving complaints about the book, the Police searched $\mathrm{Mr}$ Handyside (who was the publisher) premises and his books were seized and ultimately destroyed. The applicant was convicted of possessing obscene books for gain. Mr Handyside filed a complaint with the Court alleging, inter alia, that his conviction violated his right to freedom of expression under Convention's Article 10. The Court denied his claim and upheld the conviction. In doing so, it applied an analysis that has become standard in cases involving margin of appreciation. It stated:

"The Court points out that the machinery of protection established by the Convention is subsidiary to the national systems safeguarding human rights. The Convention leaves to each Contracting State, in the first place, the task of securing the rights and freedoms it enshrines... By reason of their direct and continuous contact with the vital forces of their countries, State authorities are in principle in a better position than the international judge to give an opinion on the exact content of these requirements as well as on the 'necessity' of a 'restriction' or 'penalty' intended to meet them... Consequently, Article 10 (2) leaves to the Contracting States a margin of appreciation. This margin is given both to the domestic legislator ('prescribed by law') and to the bodies, judicial amongst others, that are called upon to interpret and apply the laws in force" 54

And went on:

"Nevertheless, Article 10 (2) does not give the Contracting States an unlimited power of appreciation. The Court, which, with the Commission, is responsible for ensuring the observance of those States' engagements, is empowered to give the final ruling on whether a 'restriction' or 'penalty' is reconcilable with freedom of expression as protected by Article 10. The domestic margin of appreciation thus goes hand in hand with a European supervision... The Court must decide, on the different data available to it, whether the reasons given by the national authorities to justify the actual measures of 'interference' they take are relevant and sufficient under Article 10 (2)." 55

This case represents a beginning of an era of margin of appreciation and a number of cases where it was used as a doctrine is over $1,000 .^{56}$

As already pointed out, no strict conclusion can be drawn as to when the Court will use wide and when it will use a narrow approach. Even when it comes to the same case, it was sometimes decided differently by the Grand Chamber then it

\footnotetext{
${ }^{53}$ Handyside v United Kingdom (1979-80) 1 E.H.R.R. 737.

${ }^{54}$ Ibid [48].

${ }^{55}$ Ibid [49]-[50].

${ }^{56}$ Data retrieved from the HUDOC database: http://www.echr.coe.int/ECHR/EN/Header/Case-Law/ Decisions+and+judgments/HUDOC+database/. Accessed 18 August 2013.
} 
was by the Chamber. As an example we can take Lautsi $v$ Italy ${ }^{57}$ case. This case was lodged by a non-religious mother, Soile Lautsi and it was a challenge to Italy's law compelling all state schools to display crucifixes in every classroom. The applicant considered that displaying crucifixes was contrary to the principle of secularism and that it was contrary to her right to ensure their education and teaching in conformity with her religious and philosophical convictions, within the meaning of Article 2 of Protocol 1. Also, she alleged that the display of the cross had breached her freedom of conviction and religion, as protected by Article 9 of the Convention. The Chamber and the Grand Chamber delivered different judgments and both were based on the principle of the state's margin of appreciation. The Chamber took an activists approach narrowing the state's margin of appreciation and found a violation of Article 9 in conjunction with Article 2 of Protocol 1. Although the Government in its defence invoked margin of appreciation that the national authorities had in relation to such complex and sensitive questions the Chamber found that the compulsory display of a symbol of a particular faith in the exercise of public authority in relation to specific situations subject to governmental supervision, particularly in classrooms, restricts the right of parents to educate their children in conformity with their convictions and the right of schoolchildren to believe or not to believe. ${ }^{58}$

However, the Grand Chamber reached a different conclusion and found that in deciding to keep crucifixes in the classrooms of the State school attended by the applicant's children, the authorities acted within the limits of the margin of appreciation left to the respondent State in the context of its obligation to respect in the exercise of the functions it assumes in relation to education and teaching, the right of parents to ensure such education and teaching in conformity with their own religious and philosophical convictions. ${ }^{59}$

Furthermore, although more often the Court uses this doctrine to stress the Court's subsidiary role, sometimes it will be used as a judicial activist principle. A good example is a Christine Goodwin case.$^{60}$ Here, the applicant was an individual registered at birth as male, but who later underwent gender-reassignment surgery to become a woman. The applicant submitted an application to the Court in which she complained about the lack of legal recognition of the sex change she underwent claiming a violation of Article 8 of the Convention. Pursuant to her application, the Court found a violation of Article 8 stating that the respondent Government can no longer claim that the matter falls within their margin of appreciation. ${ }^{61}$ The Court thus narrowed the scope of the margin of appreciation contrary to what it did in the previous case concerning legal recognition of sex change, Rees $v$ United

\footnotetext{
${ }^{57}$ Lautsi and Others $v$ Italy (n 43). See also Hatton v United Kingdom (n 49).

${ }^{58}$ Ibid [56]-[58].

${ }^{59}$ Lautsi and Others $v$ Italy (n 43), [67]-[77].

${ }^{60}$ Goodwin v United Kingdom (n 42).

${ }^{61}$ Ibid, [93].
} 
Kingdom. ${ }^{62}$ It did so after being inspired by the evolution of the attitudes towards sex change on a world level. ${ }^{63}$

Unfortunately, there are no clear standards as to when the margin of appreciation will be wide and when it will be narrow. It can only be said that the margin of appreciation will tend be wider when there is no substantial amount of consensus among states. ${ }^{64}$ Also, where a particularly important facet of an individual's existence or identity is at stake, the margin allowed to the state will be restricted. ${ }^{65}$ However, the margin of appreciation can also contribute to the Court's inconsistency.

The margin of appreciation doctrine has often been criticised on two different levels, either in general as a doctrine ${ }^{66}$ or its use in certain circumstances. ${ }^{67}$ Harris, O'Boyle and Warbrick wrote that "when it is applied widely, so as to appear to give a state a blanq cheque or to tolerate questionable practices or decisions, it may be argued that the Court has abdicated its responsibilities." ${ }^{68}$ According to the other scholars the Court nowadays uses the margin of appreciation as a substitute for coherent legal analysis of the issues at stake, as well as to avoid very controversial judgments. ${ }^{69}$ However, scholars generally agree that the margin of appreciation doctrine can be justified, but that the problem lies in knowing when and how to apply it to the facts of particular case. ${ }^{70}$

\subsection{THE DOCTRINE OF FOURTH INSTANCE}

The doctrine of fourth instance enables the Court to refrain from excessive interfering with the decisions taken by the courts in the national justice systems of State Parties. ${ }^{71}$ The use of this doctrine can be seen in cases where the applicants

\footnotetext{
${ }^{62}$ Rees $v$ United Kingdom (1987) 9 E.H.R.R. 56 (where there were three dissenting judges claiming there was a violation of Article 8 and that the applicant ought to be treated in accordance with the sex change he has undergone).

${ }^{63}$ Although it is unclear what the Court meant when using the term 'international trend'. Goodwin v United Kingdom (n 42), [68].

${ }^{64}$ Lombardo and others v Malta (2009) 48 E.H.R.R. 23; Sunday Times v United Kingdom (1992) 14 E.H.R.R. 229.

${ }^{65} X$ and $Y v$ the Netherlands (1986) 8 E.H.R.R. 235; Dudgeon $v$ United Kingdom (1982) 4 E.H. R.R. 149.

${ }^{66}$ Brauch (n 35).

${ }^{67}$ See Judge Loucaides (former Judge of the Court) in reflections on his experience as a judge of the Court. He particularly criticizes the jurisprudence showing certain reluctance of the Court (ERRC webpage 26 May 2010) <http://www.errc.org/cikk.php?page $=8 \&$ cikk=3613> (accessed 1 June 2013); or Macdonald (n 35), 83-124.

${ }^{68}$ Harris, O’Boyle and Warbrick (n 27) 13.

${ }^{69}$ Lord Lester of Herne Hill, 'Universality versus Subsidiarity: A Reply' (1998) 1 E.H.R.L.R. 1998 73,75 .

${ }^{70}$ Ibid, 14. See also Paolo G. Carozza, 'Uses and Misuses of Comparative Law in International Human Rights: Some Reflections on the Jurisprudence of the European Court of Human Rights' (1998) 73 NOTRE DAME L. REV. 1217, 1220; and Harris, O'Boyle and Warbrick (n 27), 13.

${ }^{71}$ Popovic, The Emergence of the European Human Rights Law... (n 15), 135.
} 
filed a complaint to the Court claiming a violation of Article 6(1). For example, in Garcia Ruiz v Spain ${ }^{72}$ the applicant claimed that the appellate court judgment was not reasoned, which according to him rendered the whole procedure in his case unfair. The applicant in Perez $v$ France ${ }^{73}$ claimed that there has been a violation of his rights as guaranteed under Article 6(1) as the decision to discontinue the trial was unsound and the appeal court had failed to consider her appeal properly. In both cases the Grand Chamber unanimously held that no violation of the Convention took place and pointed out that it is not the function of the Court to deal with errors of fact or law allegedly made by a national court, unless and in so far as they may have infringed rights and freedoms protected by the Convention. It also stressed that in any event it is primarily for the national authorities, notably the courts, to resolve problems of interpretation of national legislation. ${ }^{74}$

\section{JUDICIAL ACTIVIST PRINCIPLES OF INTERPRETATION OF THE CONVENTION}

The judicial activist principles of the interpretation will be divided as follows:

- the doctrine of an autonomous concept

- $\quad$ the living instrument doctrine (the evolutive interpretation)

- $\quad$ the doctrine of effectiveness (innovative interpretation)

\subsection{THE DOCTRINE OF AN AUTONOMOUS CONCEPT}

The autonomous concept represents a specific principle of interpretation closely connected to interpreting the Convention in accordance with its object and purpose, but also with all other activist interpretative principles. This concept means that on certain occasions the Court will give an autonomous meaning to a Convention term, regardless of its meaning on a national level. Its goal is to accomplish the primary goal of the Convention, which is the protection of individual rights from being violated by the Member States. P. Mahoney defined autonomous concepts as "technical terms that are employed in national legal sources and are invested with special, non-ordinary, meaning." 75 The purpose of autonomous concept is to prevent provisions of the Convention from being "subordinated to the interpretation of a term or principle in domestic law of the contracting parties." ${ }^{76}$ The emergence of autonomous concepts began in 1971 with the Engels $v$ the Nerherlands ${ }^{77}$ judgment

${ }^{72}$ Garcia Ruiz, v Spain (2001) 31 E.H.R.R. 22.

${ }^{73}$ Perez v France (2005) 40 E.H.R.R. 39.

${ }^{74}$ Garcia Ruiz v Spain (n 73) [28]; Perez v France (n 74) [82].

${ }^{75}$ Letsas, A Theory of Interpretation... (n 34) 48.

${ }^{76}$ Human Rights Education for Legal Professionals, Key concepts of the European Convention on Human Rights (CoE September 2009), 5.

${ }^{77}$ Engel andOthers $v$ Netherlands (1979-80) 1 E.H.R.R. 647. 
Dr. sc. Maša Marochini: The interpretation of the European Convention Human Rights Zbornik radova Pravnog fakulteta u Splitu, god. 51, 1/2014., str. 63.- 84.

and it has been used widely by the Court in order to interpret a number of concepts from the Convention. ${ }^{78}$

There are some interesting features of the autonomous concept. First, the applicants claim a violation by disputing the national meaning assigned by the state to the legal concept and secondly, it is possible that the state has provided all the necessary guarantees for the protection of the right; however, the Court will find a violation since it did not do so for all the required cases. ${ }^{79}$

When using the autonomous interpretation the Court even went so far as to give a meaning to the Convention's provision contrary to the drafters' intention. Generally, the judges refrain themselves from interpreting the Convention contrary to the drafters' intention. However, in Young, James and Webster they did exactly that regarding 'negative freedom of association'. In the instant case the Government claimed that no right to 'negative freedom of association' existed under the Convention and that it has been deliberately excluded from the Convention emphasizing that including such right would be going against the drafters' intention. ${ }^{80}$ On this occasion the Court did not consider it necessary to answer the question whether Article 11 encompasses a "negative freedom of association' but it found a violation of Article 11, thereby implicitly guaranteeing the right to "negative freedom of association' ${ }^{81}$ Despite this indecisiveness of the Court in the cases following Young, James and Webster the Court acknowledged existence of the right to 'negative freedom of association' under Article 11. ${ }^{82}$

Therefore, the use of the autonomous concept allowed the Court to interpret the Convention on a level that some might understand as overstepping Courts judicial powers and even certain judges of the Court have had criticisms on using the autonomous concept in such manner. ${ }^{83}$

${ }^{78}$ Paulić v Croatia App no 3572/06 (ECtHR, 22 October 2009) (concept of home); Konig v Germany (1979-80) 2 E.H.R.R. 170 (civil rights and obligations); Stec and Others v United Kingdom (2006) 43 E.H.R.R. 47, (possessions); Intersplav v Ukraine (2010) 50 E.H.R.R. 4 (both for 'possessions' and 'civil rights and obligations'); Iatridis v Greece (2000) 30 E.H.R.R. 97 (possessions); Siliadin v France, (2006) 43 E.H.R.R. 16 (victim); Pellegrin v France (2001) 31 E.H.R.R. 26 (civil servant); Frydlender v France (2001) 31 E.H.R.R. 52; Eriksen v Norway (2000) 29 E.H.R.R. 328 (lawful detention); Chassagnou and others $v$ France (2000) 29 E.H.R.R. 615 (association).

${ }^{79}$ George Letsas, 'Strasbourg's interpretative ethics: lessons from the international lawyer' (2010) 21(3) E.J.I.L. 526, 526.

${ }^{80}$ Young, James and Webster v United Kingdom (1982) 4 E.H.R.R. 38, [51].

${ }^{81}$ Ibid [55].

82 "It was not contested by those who appeared before the Court that the obligation to join an ACCA imposed on the applicants by the Loi Verdeille was an interference with the "negative" freedom of association. The Court shares that opinion and will accordingly consider the complaint under Article 11 in the light of Article 9, since protection of personal opinions is one of the purposes of the freedom of association, which implies a negative freedom of association." Chassagnou and Others v France (n 78) [103]. See also Gustafsson v Sweden (1996) 22 E.H.R.R. 409; Sorensen and Ramussen v Denmark (2008) 46 E.H.R.R. 29; Evaldsson and others $v$ Sweden 23 B.H.R.C. 335. It is also interesting to notice that in all the above cases the majority found a violation of Article 11, but there were dissenting opinions regarding the negative freedom of association.

${ }^{83}$ Young, James and Webster v United Kingdom (n 80), dissenting opinion of Judge Sorenssen, joined by Judges Thor Vilhjalmsson and Judge Lagergen. 


\subsection{THE LIVING INSTRUMENT DOCTRINE (THE EVOLUTIVE INTERPRETATION)}

The living instrument doctrine is "one of the best known principles of Strasbourg case-law. It expresses the principle that the Convention should be interpreted 'in the light of present day conditions' and that it evolves through the interpretation of the Court." 84 The first time the Court used the term living instrument was already in the 1978 Tyrer judgment. Here, the question was whether the corporal punishment of a juvenile on the Isle of Man amounted to a degrading treatment under Article 3. In deciding this question the Court stated that it:

"(M)ust also recall that the Convention is a living instrument which, as the Commission rightly stressed, must be interpreted in the light of present-day conditions. In the case now before it the Court cannot but be influenced by the developments and commonly accepted standards in the penal policy of the Member States of the Council of Europe in this field." ${ }^{85}$

Even though the majority accepted this line of reasoning, Judge Fitzgerald issued a dissenting opinion criticising the use of the living instrument doctrine. He stressed that the Court, when claiming that institutionalised punishment must necessarily be degrading did not provide explanation for this line of thinking. ${ }^{86}$

A. Mowbray stressed that critics of judicial activism might contend that the Court in Tyrer provided little justification for or elaboration of the living instrument ${ }^{87}$ and this is true. There was no reference to Member States' criminal law, no comparative study on corporal punishment and no attempt to establish common standards of Member States in abolishing corporal punishment. ${ }^{88}$ Nowhere in the judgment can one see why the Court started using the living instrument doctrine and what is the Court justification doing so. Maybe, if the Court at the beginning of its use of this doctrine explained when and how it will be used i.e. theoretically justified it, nowadays we wouldn't be faced with numerous discrepancies. However, despite not providing reasons or justification for adopting this doctrine, the Court started regularly using it when interpreting certain Convention right. The living instrument doctrine is now widely used and accepted, ${ }^{89}$ not only by the Court but in interpretation of various provisions in international human rights law.

\footnotetext{
${ }^{84}$ Luzius Wildhaber, 'The European Court of Human Rights in Action' (2004) 21 Ritsumeikan Law Review 83, 84.

${ }^{85}$ Tyrer $v$ United Kingdom (1979-80) 2 E.H.R.R. 1 [31].

${ }^{86}$ Ibid, separate opinion of Judge Sir Gerald Fitzmaurice [9].

${ }^{87}$ Mowbray (n 19), 61.

${ }^{88}$ Letsas, A Theory of Interpretation... (n 34), 76.

${ }^{89}$ Selmouni v France (2000) 29 E.H.R.R. 403 [102]; Hatton and Others $v$ United Kingdom (GC judgment) (n 49), Joined dissenting opinion of Judges Costa, Ress, Turmen, Zupančič and Steiner [2]; Soering v United Kingdom (1989) 11 E.H.R.R. 439 [102]; Henaf v France (2005) 40 E.H.R.R. 44 [55]; Sandra Janković v Croatia App no 38478/05 (ECtHR, 14 September 2009) [47]; Beganović v Croatia App no 46423/06 (ECtHR, 25 September 2009) [66].
} 
Next significant judgment where the living instrument doctrine was used is Marckx $v$ Belgium $^{90}$ where the Court had to decide whether Belgian legislation that drew distinction between legitimate and illegitimate children violated Article 8 of the Convention. The Court has admitted that there is no European consensus on the issue, however, it stated:

"Both the relevant Conventions (the Brussels Convention and the European Convention of 15 October 1975 on the Legal Status of Children born out of Wedlock, emphasis added) are in force and there is no reason to attribute the currently small number of Contracting States to a refusal to admit equality between "illegitimate" and legitimate" children on the point under consideration. In fact, the existence of these two treaties denotes that there is a clear measure of common ground in this area amongst modern societies." 91

Therefore, the Court anticipated European trends before they actually occurred invoking the mere existence of the two Conventions. This judgment was not reached unanimously, but with strong dissenting opinions. ${ }^{92}$

Although the living instrument doctrine is nowadays often used, the Court still refrains from using it in sensitive cases. A good example is $A, B$ and $C v$ Ireland $^{93}$ case concerning the right to abortion. Here, the first and second complainants, two Irish women who had sought abortions, complained that the Ireland's prohibition of abortion on health and well-being grounds violated their rights under Article 8. They both travelled abroad to have abortions as they considered that having children would jeopardise their health and both suffered subsequent medical complications. The third complainant, who had cancer which was in remission, travelled abroad for an abortion believing that the pregnancy increased the risk of her cancer returning thereby posing a risk to her life. The first two applicants contended that the prohibition disproportionately restricted their right to respect for their private lives. The third applicant contended that the state's failure to legislatively implement the constitutional life-saving provision meant that she was unable to establish whether she would have qualified for an abortion in Ireland. While regarding the third applicant the Court found a violation of Article 8 , regarding the first two applicants the Court found no violation.

It is interesting to look at the Court's reasoning in this case since the Court accepted that there is a consensus amongst a substantial majority of the Contracting States of the CoE towards allowing abortion on broader grounds than accorded under Irish law. Ireland is the only State which allows abortion solely where there is a risk to the life (including self-destruction) of the expectant mother. However, the Court did not consider that this consensus decisively narrows the broad margin

${ }^{90}$ Marckx v Belgium (1979-80) 2 E.H.R.R. 330.

${ }^{91}$ Ibid, [41].

${ }^{92}$ Ibid, Judge Matscher, in his dissenting opinion, strongly disagreed with the judgment on Article 8 as well as Judge Bindschedler- Robert. However, the strongest disagreement came from Judge Fitzmaurice.

${ }^{93} A, B$ and $C v$ United Kingdom App No 25579/05 (ECtHR, 16 December 2010). 
of appreciation of the State ${ }^{94}$ and it rejected the use of the living instrument, resorting to the state's broad margin of appreciation. This decision was strongly criticised by the dissenting judges. ${ }^{95}$

Another case where the Court's discretionary use of the living instrument is visible is Hatton $v$ United Kingdom. In the instant case, the applicants complained that the Government's policy on night flights at Heathrow airport violated their rights under Article 8. The Chamber, five votes to two, held that mere reference to the economic well-being of the country is not sufficient to outweigh the rights of others. Two judges issued dissenting opinions invoking the Court's too wide use of the living instrument doctrine as well as stating that the Court has impermissibly narrowed the margin of appreciation attributed to states..$^{96}$ Later on, the case was referred to the Grand Chamber that found no violation of Article 8. The majority of the Grand Chamber did not find that the authorities overstepped their margin of appreciation. However, here also five judges issued a join dissenting opinion advocating a stronger role for the Court in responding to complaints concerning environmental pollution, invoking the use of the living instrument doctrine. ${ }^{97}$

Finally, the use of the living instrument doctrine is also visible in the interpretation of the Article 3 when guaranteeing the right to have satisfactory detention conditions and healthcare of certain standard in prisons. The Court has from 2001 started imposing those obligations on states under Article 3. In Dougoz $v$ Greece ${ }^{98}$ the first case where the Court found a violation of Article 3 based on poor detention conditions, ${ }^{99}$ it did not directly refer to the living instrument doctrine. However, it can be concluded that the Court did find a violation of Article 3 by using the living instrument doctrine, without referring to it explicitly and without providing justification for such reasoning. If we bear in mind that the Court was reluctant in finding a violation of Article 3 based on poor detention conditions and unsatisfactory healthcare in prisons prior to 2001, we can conclude that it was the use of living instrument doctrine that led to these developments, so that detention conditions that did not satisfy the minimum level of severity as to represent a violation of Article 3 in the past, nowadays will. Whether or not the Court explicitly invoked it, it is clear that it was the use of this doctrine that allowed the Court to extend the scope of Article 3's protections.

What can be concluded is that, like with the margin of appreciation doctrine, if the Court at the beginning of its use of this doctrine explained when and how it will be used maybe nowadays we wouldn't be faced with such discrepancies.

\footnotetext{
${ }^{94}$ Ibid, [235] and [236].

${ }^{95}$ Ibid, joint partly dissenting opinion of Judges Rozakis, Tulkens, Fura, Hirvera, Malinverni and Poalelungi. The dissenters were of the opinion that Article 8 was violated regarding the first two applicants.

${ }^{96}$ Hatton and Others $v$ United Kingdom (n 49), partly dissenting opinion of Judge Greve.

${ }^{97}$ Hatton and Others $v$ United Kingdom (GC) (n 49), Joint dissenting opinions of Judges Costa, Rees, Turmen, Zupancic and Steiner.

${ }^{98}$ Dougoz v Greece (2002) 34 E.H.R.R. 61.

${ }^{99}$ Besides the Greek case (1969) 12 YB 170 EComHR.
} 


\subsection{THE DOCTRINE OF EFFECTIVENESS (INNOVATIVE INTERPRETATION)}

By introducing and using the doctrine of effectiveness, the Court is giving provisions of the Convention the "fullest weight and effect consistent with the language used and with the rest of the text and in such a way that every part of it can be given meaning." ${ }^{100}$ The essence of this approach is that states cannot be in compliance with the Convention simply by prohibiting conduct that contravenes the Convention, but they might have to take positive action to protect its rights. ${ }^{101}$ Therefore, the general idea under this approach is to impose positive obligations on the Contracting States. The principle of effectiveness is used by the Court either when it decides whether a provision is applicable or whether a clearly applicable provision has been violated.

The first judgment where the doctrine of effectiveness was used was Golder ${ }^{102}$ and already here the use of this doctrine was controversial, since in a way, the Court introduced a new right under the Convention. The question was whether the right of access to a court is guaranteed under Article 6 since the text of Article 6 provides only rights to individuals who are already before the Court. The Court decided to ignore the intention of the drafters and said:

"Taking all the preceding considerations together, it follows that the right of access constitutes an element which is inherent in the right stated by Article 6 para. 1. This is not an extensive interpretation forcing new obligations on the Contracting States: it is based on the very terms of the first sentence of Article 6 para. 1 read in its context and having regard to the object and purpose of the Convention, a lawmaking treaty (see the Wemhoff judgment of 27 June 1968, Series A no. 7, p. 23, para. 8), and to general principles of law." 103

The issue of effective access to a court has been invoked before the Court on numerous other occasions, for example in Airey $v$ Ireland, ${ }^{104} P, C$ and $S v$ United Kingdom ${ }^{105}$ and Artico v Italy. ${ }^{106}$

The Court continued with the use of the doctrine of effectiveness in numerous other matters. Regarding Article 8 of the Convention, through the doctrine of effective interpretation began the development of numerous positive obligations. Two cases are most relevant for this development, Marckx $v$ Belgium and $X$ and $Y$

${ }^{100}$ Merrills (n 16), 89.

${ }^{101}$ Donald McRae, 'Approaches to the Interpretation of Treaties: The European Court of Human Rights and the WTO Appellate Body' in Stephan Breintenmoser, Bernhard Ehrenzeller et al (eds), Human Rights, Democracy and the Rule of Law: Liber amicorum Luzius Wildhaber (Nomos Verlagsgesellschaft (2007), 1411-1412.

\footnotetext{
${ }^{102}$ Golder v United Kingdom (n 18).

${ }^{103}$ Ibid [36].

${ }^{104}$ Airey v Ireland (1979-80) 2 E.H.R.R. 305.

${ }^{105}$ P, $C$ and $S v$ United Kingdom (2002) 35 E.H.R.R. 31.

${ }^{106}$ Artico v Italy (1981) 3 E.H.R.R. 1.
} 
$v$ the Netherlands. ${ }^{107}$ The Marckx case was already mentioned in the context of the living instrument doctrine where the Court anticipated European trends. However, it can be mentioned here as well since the Court used the combination of the two interpretative principles. ${ }^{108}$ In the context of the doctrine of effectiveness and reading in positive obligations for the states, the Court- when deciding whether a Belgian law that placed a mother and her daughter under legal disadvantages where the daughter was 'illegitimate' and the mother had to adopt the child if she wanted to increase his rights- stated:

"By proclaiming in paragraph 1 the right to respect for family life, Article 8 (art. 8-1) signifies firstly that the State cannot interfere with the exercise of that right otherwise than in accordance with the strict conditions set out in paragraph 2 (art. 8-2). As the Court stated in the "Belgian Linguistic" case, the object of the Article is "essentially" that of protecting the individual against arbitrary interference by the public authorities (judgment of 23 July 1968, Series A no. 6, p. 33, para. 7). Nevertheless it does not merely compel the State to abstain from such interference: in addition to this primarily negative undertaking, there may be positive obligations inherent in an effective "respect" for family life...In this connection, the State has a choice of various means, but a law that fails to satisfy this requirement violates paragraph 1 of Article 8." 109

Judge Fitzmaurice, as one of the dissenting judges, strongly disagreed not only with the finding of violation of Article 8 but also with applicability of the same Article. ${ }^{110}$ Despite the dissenting opinions expressed, with this case the Court introduced positive obligations on states to ensure that an individual is not "disadvantaged by positive action." 111

The latter case $X$ and $Y v$ Netherlands extended states' positive obligations to relations between individuals themselves. In this case $\mathrm{X}$, the father of $\mathrm{Y}$, claimed that $\mathrm{Y}$ has been denied the protection of criminal law in respect of sexual assault. Y was a 16 year old mentally handicapped girl who, after being sexually assaulted, was unable to appeal to the prosecutor's office decision not to prosecute, partly on the ground that although she was incapable of making the complaint herself, no-one else was entitled to complain on her behalf. Among other provisions, the applicants claimed a violation of Article 8 because of the lacuna in Dutch law which created inability to bring criminal charges against the assaulter. The Court, when deciding whether a violation occurred, stated that although the object of Article 8 is essentially that of protecting the individual against arbitrary interference by the public authorities, it does not merely compel the State to abstain from such

\footnotetext{
${ }^{107} X$ and $Y v$ the Netherlands (n 65).

108 Just like it did in the Hatton case (n 49).

${ }^{109}$ Marckx v Belgium (n 90) [31].

${ }^{110}$ Ibid, dissenting opinion of Judge Fitzmaurice [6]- [16].

${ }^{111}$ Merrills (n 16), 95.
} 
interference: in addition to this primarily negative undertaking, there may be positive obligations inherent in an effective respect for private or family life. ${ }^{112}$

As one can see, the Court went one step further then in Marckx v Belgium, finding that the State has a duty to respect for private life even in the sphere of the relations between individuals.

After these two judgments, invoking state's positive obligations under Article 8 became a common practice of the Court on numerous Article 8 rights as well as on other Convention rights and freedoms. ${ }^{113}$ It was the doctrine of effectiveness that allowed the Court broad interpretation of the Convention's provisions so as to introduce the right to a healthy environment, ${ }^{114}$ or even the right to healthcare, ${ }^{115}$ and the right to adequate housing. ${ }^{116}$ Although the Court very rarely explicitly invoked the doctrine of effectiveness, just like with the living instrument doctrine, it did so implicitly. By requiring states to take positive and effective measures to secure the Convention rights, even the ones not explicitly included in the Convention, the Court used the doctrine of effectiveness.

Just like any other principle of interpretation, the doctrine of effectiveness is not limitless. The Convention is not intended for the protection of all human rights and the Court cannot extend its scope without limits. The Court itself has on occasions refused to read into the Convention deliberately omitted from the Convention. For example, in Johnston v Ireland ${ }^{117}$ the Court decided that, even taking into consideration the doctrine of effectiveness, the right to divorce was deliberately excluded from the Convention or in Pretty $v$ United Kingdom ${ }^{118}$ where the Court held that the right to life guaranteed by Article 2 could not be interpreted as conferring a right to die. However, the problem is that, in order to protect the rights of individuals, even the ones not implicitly or explicitly guaranteed under the Convention, the Court can almost always extend the scope of the right by using the doctrine of effectiveness.

${ }^{112} X$ and $Y v$ the Netherlands (n 65) [23].

113 See: Abdulaziz, Cabales and Balkandali $v$ United Kingdom (n 44) for effective interpretation of the right to respect for family life; McCann and Others v United Kingdom (1996) 21 E.H.R.R. 97 and Anguelova v Bulgaria (2004) 38 E.H.R.R. 31 on the right to life; Soering v United Kingdom (1989) 11 E.H.R.R. 439 on the prohibition of ill-treatment; Plattform Arzte fur das Leben v Austria (1991) 13 E.H.R.R. 204 and Church of Scientology Moscow v Russia (2008) 46 E.H.R.R. 16 on the freedom of association; Ozgur Gundem v Turkey (2001) 31 E.H.R.R. 49 on the freedom of expression; Folgero and Others $v$ Norway (2008) 46 E.H.R.R. 47 on the right to education; Yordanova and Others $v$ Bulgaria App no 25446/06 (ECtHR, 24 April 2012) on the right to respect for home; Fadeyeva v Russia (2007) 45 E.H.R.R. 10 and Onerylidiz v Turkey (2005) 41 E.H.R.R. 20 on the right to a healthy environment.

${ }^{114}$ Moreno Gomez v Spain (2005) 41 E.H.R.R. 40 [53]-[56]; Leon and Agnieszak Kania v Poland App no 12605/03 (ECtHR, 21 July 2009) [99].

${ }^{115}$ Georgel and Georgeta Stoicescu v Romania App no 9718/03 (ECtHR, 26 July 2011) [59].

${ }^{116}$ Yordanova and Others v Bulgaria (n 114) [129].

117 Johnston v Ireland (n 33).

${ }^{118}$ Pretty v United Kingdom (2002) 35 E.H.R.R. 1. 


\section{CONCLUSION}

What interpretative principle will prevail to a large degree depends on the composition of the judges sitting in the Chamber that adopts a judgment (or in some cases the Grand Chamber). It cannot be said that some judges always take an activist approach or that some always take a self-restraint approach. In the 1970's the distinction was much clearer. For example, Judge Fitzmaurice was the strongest supporter of the self-restraint approach, which is visible from his dissenting opinions elaborated in his judgments. ${ }^{119}$ However, as Judge Wildhaber, a former president of the Court said:

"One of the judges may move ahead and when the composition of the Chamber is favourable, the majority may do something very activist. If you then follow precedent, you are bound to follow the outcome of judicial activism. As a result, you can be on the side of judicial self-restraint and at the same time you want to change precedent. Because of the complexities of our Court it is not a simple continuum. Are you to the same extent a judicial activist when it concerns your own country? You know your own system, you know it works and you think it hasn't led to many abuses. Even as a very objective observer you may be more lenient towards your own country." 120

Unfortunately, today it is not clear when and why the Court resorts to certain interpretative principle. Although on most occasions the Court points out the need for effective and practical protection of rights in accordance with the current day conditions, thereby using the living instrument and the doctrine of effectiveness, it occasionally returns to the judicial self-restraint principles of interpretation.

The overreaching conclusion that can be reached is that the Court's approach is objective and teleological. In the authors' opinion, judicial activism is necessary (not only under the Convention but in all human rights treaties), particularly for the reasons stressed by the Court- in order to safeguard the Convention's object and purpose as an effective human rights instrument and to prevent the states from circumventing the Convention's guarantees. However, "the Strasbourg organs are not empowered to transform by judicial fiat the meaning attributed by the Contracting States to such procedural or structural provisions, or to add to these provisions a meaning which does not find explicit support in the text." ${ }^{121}$

Another problematic issue arises because the Court often does not provide justifications for choosing one or the other interpretative principle. As seen in the paper, the Court has, in Banković case expressly referred to the preparatory work to emphasize that "preparatory material constitutes clear confirmatory evidence of the ordinary meaning of Article 1 of the Convention as already identified by the

${ }^{119}$ For example see Judge Fitzmaurice dissenting opinions in the cases: Golder v United Kingdom (n 18); Guzzardi v Italy (1981) 3 E.H.R.R. 333; and Tyrer v United Kingdom (n 85).

${ }^{120}$ Robin C.A. White and Iris Boussiakou, 'Separate Opinions in the European Court of Human Rights' (2009) 9 Hum. Rts. L. Rev. 37, 45.

${ }^{121}$ Heribert Golsong 'Interpreting the European Convention on Human Rights Beyond the Confines of the Vienna Convention on the Law of Treaties' in Macdonald, Matscher and Petzold (eds) (n 35), 150. 
Court" 122 after years of rejecting intentionalism. As to the margin of appreciation, the situation is even more slippery since there are no clear standards as to when the margin of appreciation attributed to states will be broad and when it will be narrow. Even when it comes to the same factual situation, the Chamber and the Grand Chamber have occasionally reached different conclusions basing their decisions on the doctrine of margin of appreciation. Furthermore, we have also seen that already at the beginning of the use of the living instrument doctrine the Court failed to provide justification as to when and how it will use it ${ }^{123}$ and for that reason we are today facing inconsistency in the Court's jurisprudence. Finally, the use of the doctrine of effectiveness is the most controversial since it allows the Court to broadly interpret the Convention provisions with no clear limits or standards of the Court's interpretation.

Therefore, the Court's use of numerous interpretative principles, as better for human rights protection it often might be, can raise numerous problematic issues, particularly when there are no clear standards as to when and how the Court will use each of the principles discussed in the paper.

\section{O TUMAČENJU EUROPSKE KONVENCIJE O LJUDSKIM PRAVIMA}

Europska konvencija za zaštitu ljudskih prava najstariji je i najučinkovitiji sustav za zaštitu ljudskih prava u svijetu. No, konvencijski sustav nije bez problema. Europski sud za ljudska prava, zadužen za ispitivanje individualnih (ali i međudržavnih) tužbi, preplavljen je zahtjevima pojedinaca koji tvrde da im je povrijeđeno neko od prava zajamčenih Konvencijom, te prođe i po nekoliko godina od dana podnošenja zahtjeva Sudu do dana donošenja presude. Nekoliko je razloga za ovakvu situaciju od kojih je jedan, koji je ujedno i najvažniji za ovaj rad, šrroko tumačenje konvencijskih prava od strane Suda. Kad tumači i primjenjuje konvencijska prava, Sud u pravilu usvaja jedan od sljedeća dva pristupa: samoograničavajući pristup ili aktivistički pristup. Samoograničavajući pristup označava situaciju u kojoj se Sud u konkretnom slučaju suzdržava proglasiti mjere tužene države suprotnima Konvenciji. Za razliku od toga, aktivistički pristup označava situaciju u kojoj Sud u konkretnom slučaju ocjenjuje mjere tužene države suprotnima Konvenciji čak kada Konvencija ne sadrži izričita mjerila za takvu ocjenu. U potonjem slučaju, Sud često stvara nova prava pod krinkom tumačenja postojećih konvencijskih prava. U radu su kroz judikaturu Suda prikazane sve metode tumačenja konvencijskih prava. Konačno, autorica tvrdi da široki pristup tumačenju Konvencije od strane Suda, koliko god bio hvalevrijedan s obzirom na pozitivne učinke koje ima unutar konteksta zaštite nekih konvencijskih prava, ima i određene negativne učinke, od kojih se posebno ističe nedosljednost judikature Suda.

Ključne riječi: ECHR, ECtHR, Strasbourg, konvencijsko pravo

\footnotetext{
${ }^{122}$ Bankovic and Others v Belgium and Others (n 29) [65].

${ }^{123}$ Tyrer $v$ United Kingdom (n 85).
} 